\title{
Review
}

\section{Recent Progress in Research and Technology on Soybeans}

\author{
Danji FUKUSHIMA
}

Kikkoman Corporation, Noda, Chiba 278-0037, Japan

Received December 12, 2000, Accepted January 11, 2001

\begin{abstract}
For a long time, it had been considered that soybean storage proteins play only a role as traditional nutrients and other soybean minor constituents such as isoflavones, saponins, trypsin inhibitors, phytic acid, lectin, etc., act as antinutrient factors. At present, however, these substances have all been recognized to have exciting roles in the prevention of heart disease, cancer, osteoporosis, etc. Besides these physiological effects, soybean storage proteins exhibit excellent functional properties physicochemically in food systems, such as gelation, binding, emulsification, fat and water absorption, etc. On the other hand, there are some substances having undesirable properties in soybeans, such as offflavors, allergens, etc. Recently, there was a great progress in the research of a molecular basis on these functionalities, off-flavors, and allergenicities. By applying these results for soybean breeding, the creation of the new cultivars or lines having more improved properties is in progress. Another highlight in soybean research is the success of the crystallization of $\beta$-conglycinin and glycinin and the subsequent complete determination of their three-dimensional molecular structures through X-ray crystallographic analysis. This paper overviews these recent investgations.
\end{abstract}

Keywords: soybean, $\beta$-conglycinin, glycinin, physiological function, three-dimensional structure, isoflavone, lypoxygenase-free, allergen-less

\section{Introduction}

For more than 2000 years have people throughout East Asia consumed soybeans in the form of traditional soy foods, such as nimame (cooked whole soy), edamame (green fresh soy; Fukushima, 2000a), soy milk (Fukushima, 1994), tofu (Fukushima, 1981), kori-tofu (freeze-denatured and dry tofu; Fukushima, 1980 and 1994), abura-age (deep-fat-fried tofu; Fukushima, 1981), sufu or tofu-yo (fermented tofu; Fukushima, 1981 and 1985), soy sauce (Fukushima, 1985 and 1989), miso (Fukushima, 1985), natto (Fukushima, 1985), tempeh (Fukushima \& Hashimoto, 1980), etc. In Western countries, soybeans had become to draw people's attention in 1960s as an economical and high quality vegetable protein source for humans. In the United States, new soy protein products were developed, such as soy flour, soy protein concentrates, soy protein isolates, and their texturized products. These soy products were introduced into Japan at the end of 1960s, but their consumption remains only 40,000 metric tons as products (see Table 1). The consumption of soybeans as foods in Japan is mostly to the traditional soy foods, for which about one million metric tons of soybeans and soybean meal are used, as shown in Table 1. The manufacturing techniques and equipments of these traditional soy foods had made a great progress through the technical innovations after the World War II and the modernization of the manufacturing had almost been achieved, until the end of 1980 .

In Western countries, the history of soybeans for human consumption is only several decades, where the non-traditional protein products described above are mainly used as ingredients in formulated foods for their functional properties, such as water and fat absorption, emulsification, foaming, gelation, binding, etc. These soy foods have penetrated steadily into Western coun-

E-mail: danjif@ka 2.so-net.ne.jp tries as healthy foods, but the growth is not so high as they expected, perhaps owing to their strong off-flavors associated with their products. However, the consumption of soy foods in the United States has begun to increase abruptly with a turning point in 1997 (Liu, 2000). Undoubtedly, this increase is due to the penetration of the recognition that soybeans possess the exciting physiological functions. Namely, numerous investigations during the 1990s put soybeans in the spotlight, where soybean storage proteins and soybean minor components traditionally considered to be antinutritional factors have been recognized to have exciting roles in the prevention of chronic disease. Furthermore, FDA authorized "Soy Protein Health Claim" on October 26,1999 , that 25 grams of soy protein a day may reduce the risk of heart disease. Since the market is very much responsive to this Health Claim, soy foods will penetrate rapidly into Western cultures and diets.

In the processing and utilization of soybeans, the following four points are very important. One is the nutritional and physiological aspects, the second is the functional properties working in food systems, the third is the unfavorable substances such as offflavors, allergens, etc., and the forth is the creation of the beneficial cultivars and lines. This paper deals with the review on the recent progress in these subjects.

\section{Physiological Functions of Soybeans and Soy Food Prod- ucts}

Reevaluation of nutritive value of soybean storage proteins The quality of soybean proteins has actually been undervalued until recently, because the protein efficiency ratio was based upon the growth of laboratory rats. Growing rats not only possess a much higher requirement for proteins than infants, but also a much higher need for certain amino acids than humans (Steinke, 1979). Particularly, the rat requirement for methionine 
Table 1. Consumption of traditional soy food products in 1998 in Japan.

\begin{tabular}{|c|c|c|c|}
\hline & Soybeans $^{a)}$ & Soybean meal ${ }^{b)}$ & Total \\
\hline Tofu and its derivatives & 496,000 & 0 & 496,000 \\
\hline Kori-tofu & 28,000 & 0 & 28,000 \\
\hline Natto & 128,000 & 0 & 128,000 \\
\hline Miso & 162,000 & 0 & 162,000 \\
\hline Soy sauce & 26,300 & 157,600 & 183,900 \\
\hline Soy milk & 4,200 & 0 & 4,200 \\
\hline Major traditional products (Total above) & 844,500 & 157,600 & $1,002,100$ \\
\hline Non-traditional products (Soy proteins) & & 4,000 (as product) & 4,000 (as product) \\
\hline Food use total & $1,032,000$ & $401,000^{c)}$ & $1,433,000^{c)}$ \\
\hline
\end{tabular}

Source: ${ }^{a}$ Shokuhin Sangyou Shinbunsha and ${ }^{b}$ Ministry of Agriculture, Forestry, and Fishery. ${ }^{c}$ Including non-food meal other than feeds.

Table 2. Patterns of amino acid requirements and soybean amino acid composition.

\begin{tabular}{|c|c|c|c|c|c|}
\hline \multirow{2}{*}{$\begin{array}{c}\text { Amino acid } \\
(\mathrm{mg} / \mathrm{g} \text { protein })\end{array}$} & \multicolumn{4}{|c|}{ Pattern of requirement } & \multirow{2}{*}{$\begin{array}{c}\text { Amino a. comp } \\
\text { of soybeans }\end{array}$} \\
\hline & 3-4 Mo. & $2-5 \mathrm{Yr}$ & $10-12$ Yr. & Adult & \\
\hline His & 26 & 19 & 19 & 16 & 27 \\
\hline Ile & 46 & 28 & 28 & 13 & 48 \\
\hline Leu & 93 & 66 & 44 & 19 & 78 \\
\hline Lys & 66 & 58 & 44 & 16 & 61 \\
\hline Met + Cys & 42 & 25 & 22 & 17 & 26 \\
\hline Phe +Tyr & 72 & 63 & 22 & 19 & 90 \\
\hline Thr & 43 & 34 & 28 & 9 & 35 \\
\hline $\operatorname{Trp}$ & 17 & 11 & 9 & 5 & 13 \\
\hline Val & 55 & 35 & 25 & 13 & 48 \\
\hline Total (Including His) & 460 & 339 & 241 & 127 & 426 \\
\hline Total (Minus His) & 434 & 320 & 222 & 111 & 399 \\
\hline
\end{tabular}

Source: Joint FAO/WHO/UNU Expert Consultation (1985).

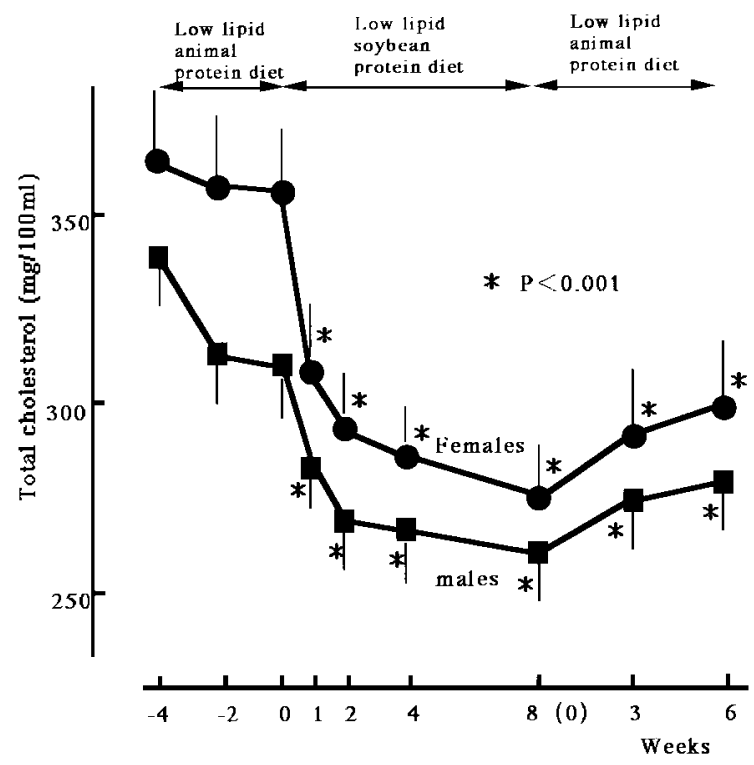

Fig. 1. Total cholesterol levels in type II patients treated with soy protein diets. Mark (*) indicates highly significant difference from mean plasma lipid levels during the term before soy protein diets. Source: Descovich et al. (1980).

is about 50\% higher (Sarwar, 1985). According to the Report of a Joint FAO/WHO/UNU Expert Consultation in 1985, the amino acid requirements are different depending upon human age and methionine is not a limiting amino acid for soybean proteins, except infants (see Table 2; Fukushima, 1991a). Both the World Health Organization (WHO) and the United States Food and
Table 3. Meta-analysis of effects of soy protein intake.

\begin{tabular}{lccccr}
\hline & $\begin{array}{c}\text { No. of } \\
\text { studies }\end{array}$ & $\begin{array}{c}\text { No. of } \\
\text { subjects }\end{array}$ & $\begin{array}{c}\text { Change } \\
(\mathrm{mg} / \mathrm{dl})\end{array}$ & $\begin{array}{c}95 \% \\
\mathrm{CI}^{a)}\end{array}$ & $\begin{array}{c}\text { Change } \\
(\%)\end{array}$ \\
\hline Total cholesterol & 38 & 730 & -23.2 & $-32.9 \sim-13.5$ & -9.3 \\
LDL cholesterol & 31 & 564 & -21.7 & $-31.7 \sim-11.2$ & -12.9 \\
HDL cholesterol & 30 & 551 & +1.2 & $-3.1 \sim+5.4$ & +2.4 \\
VLDL cholesterol & 20 & 255 & -0.4 & $-4.6 \sim+3.9$ & -2.6 \\
Triglyceride & 30 & 628 & -13.3 & $-25.7 \sim-0.3$ & -10.5 \\
\hline${ }^{a)}$ Confidence interval. Source: Anderson et al. (1995).
\end{tabular}

Drug Administration (FDA) adopted the protein digestibility corrected amino acid score (PDCAAS) as the official assay for evaluating protein quality. Soybean proteins have a PDCAAS of 1.0, indicating that it is able to meet the protein needs of children and adults when consumed as the sole source of protein at the recommended level protein intake of $0.6 \mathrm{~g} / \mathrm{kg}$ body wt. (Young, 1991). It is now concluded that the quality of soybean proteins is comparable to that of animal protein sources such as milk and beef.

Physiological functions of soybean storage proteins Formerly, soybean proteins had been considered to play only a role as traditional nutrients. In the latter half of 1970s, however, it was found that soybean proteins have a hypocholesterolemic effect. As shown in Fig. 1 (Descovich et al., 1980), the animal proteins in the diet are exchanged with soybean proteins, the serum cholesterol is lowered markedly. Since then, numerous investigations on the hypocholesterolemic effect of soybean proteins have been carried out. According to a meta-analysis of 38 separate studies involving 743 subjects, the consumption of soy protein resulted in significant reduction in total cholesterol 
(9.3\%), LDL cholesterol (12.9\%), and triglycerides (10.5\%), with a small but insignificant increase (2.4\%) in HDL cholesterol (see Table 3; Anderson et al., 1995). In linear regression analysis, the threshold level of soy intake at which the effects on blood lipids became significant was $25 \mathrm{~g}$. Thus, soy protein represents a safe, viable, and practical nonpharmacologic approach to lowering cholesterol. It is clear that soybean storage proteins possess the hypocholesterolemic effect in themselves, because the plasma total cholesterol of the rats fed casein-cholesterol diets was reduced by 35 and $34 \%$ by the administration of purely isolate $\beta$ conglycinin and glycinin, respectively (Lovati et al., 1992). The exact mechanism of the cholesterol reduction has not been established fully. Some suggest that cholesterol absorption and/or bile acid reabsorption is impaired, when soybean proteins are fed, while others propose that changes in endocrine status, such as alteration in insulin to glucagon ratio and thyroid hormone concentrations, are responsible (Potter, 1995).

In addition to the cholesterol-lowering effects described above, soybean proteins suppress the lipogenic enzyme gene expression in the livers of genetically fatty rats (Wistar fatty rats), indicating that dietary soybean proteins are useful for the reduction of body fats (Iritani et al., 1996).

Physiologically active fragments derived from soybean storage protein molecules It has been suggested that some hydrophobic polypeptides produced through proteolytic hydrolysis of soybean proteins, which bind well to bile acids, are involved in the hypocholesterolemic effect of soybean proteins (Iwami et al., 1986; Sugano et al., 1988). Minami et al. (1990) found that the $A_{1 a}$ and $A_{2}$, the acidic polypeptides of the glycinin subunits $A_{1 a} B_{1 b}$ and $A_{2} B_{1 a}$, strongly combine to bile acids. Further, they obtained the peptide fraction of Ile (114)-Arg (161) with 48 amino acid residues through a tryptic digestion of $\mathrm{A}_{1 \mathrm{a}}$ peptide. This peptide has a high hydrophobicity and provides a binding site to bile acids.

Besides these, there are many physiologically active peptide fragments derived from storage protein molecules, which have antioxidative activities (Chen et al., 1995), the inhibitory action for angiotensin converting enzymes (Kawamura, 1997), or the promoting action for phagocytosis (Yoshikawa et al., 1993), as shown in Table 4.

Physiological functions of soybean minor com-

Table 4. Physiologically active peptide fragments from soybean storage protein.

\begin{tabular}{|c|c|c|}
\hline & Peptide fragments & Protein source \\
\hline $\begin{array}{l}\text { Antioxidant } \\
\text { activities }\end{array}$ & $\begin{array}{l}\text { VNPHQN }^{a)} \\
\text { LVNPHDHQN }^{a)} \\
\text { LLPHH }^{a)} \\
\text { LLPHHADADY }^{a)} \\
\text { VIPAGYP }^{a)} \\
\text { LQSGDALRVPSGTTYY }^{a)}\end{array}$ & $\begin{array}{l}\beta \text {-Conglycinin } \\
\beta \text {-Conglycinin } \\
\beta \text {-Conglycinin } \\
\beta \text {-Conglycinin } \\
\beta \text {-Conglycinin } \\
\beta \text {-Conglycinin }\end{array}$ \\
\hline $\begin{array}{l}\text { Inhibition of } \\
\text { angiotensin- } \\
\text { converting } \\
\text { enzymes }\end{array}$ & $\begin{array}{l}\text { FVIPAGY }^{b)} \\
\text { ASUDTLF }^{b)} \\
\text { DQTPRVF }^{b)} \\
\text { YRILEF }^{b)}\end{array}$ & $\begin{array}{l}\alpha, \alpha^{\prime}(\beta-\text { Conglycinin subunit) } \\
\alpha, \alpha^{\prime}(\beta-\text {-Conglycinin subunit) } \\
A_{5} A_{4} B_{3} \text { (Glycinin subunit) } \\
\alpha^{\prime}(\beta-\text { Conglycinin subunit })\end{array}$ \\
\hline $\begin{array}{l}\text { Promoting } \\
\text { action of } \\
\text { phagocytosis }\end{array}$ & $\begin{array}{l}\text { MITLAIPVNKPGR }^{c)} \\
\text { HCQRPR }^{d)} \\
\text { QRPR }^{d)}\end{array}$ & $\begin{array}{l}\alpha^{\prime}(\beta-\text { Conglycinin subunit) } \\
A_{1 a} B_{1 b} \text { (Glycinin subunit) } \\
A_{1 a} B_{1 b} \text { (Glycinin subunit) }\end{array}$ \\
\hline
\end{tabular}

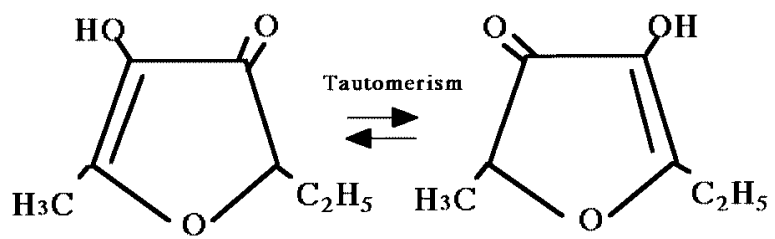

Fig. 2. 4-Hydroxy-2(or 5)-ethyl-5(or 2)-methyl-3(2H)-furanone. Abbreviated as HEMF.

ponents Another importance in the physiological action of soybeans is that soybean minor components have exciting roles in the prevention of chronic disease (see Table 5). Hitherto, these minor components, such as isoflavones, saponins, trypsin inhibitors, phytic acid, lectin, etc., were thought to be antinutritional factors, but now they are recognized to have preventing effects on cancer (Messina \& Barnes, 1991). Among these, isoflavones (mainly genistein and daidzein) are particularly noteworthy, because soybeans are the only significant dietary source of these compounds. Isoflavones have not only anticarcinogenic activities, but also the preventive effects on osteoporosis (Anderson \& Garner, 1997) and the alleviation of menopausal symptoms (Albertazzi et al., 1998).

Physiologically functional substances produced by microorganisms contained in fermented soy foods The physiologically functional substances described above are the components originally contained in soybeans. Besides these substances, however, some of the traditional fermented soy foods, such as soy sauce, miso, natto, and tempeh, have the physiologically active substances which are produced by microorganisms. Particularly, it is very interesting that HEMF (see Fig. 2), the key flavor component in Japanese-style fermented soy sauce, has quite a strong anticarcinogenic activity (Nagahara et al., 1992). HEMF is biosynthesized through the pentose-phosphate cycle by the yeast during the fermentation (Sasaki, 1996). Therefore, it is not present at tamari-type soy sauce, because of the lack of yeast fermentation. HEMF is a very unique compound which is not contained in foods other than Japanese-style fermented soy sauce and miso (Sasaki, 1996). The HEMF content in miso is low, namely around 0-7 ppm (Sugawara, 1991; Hayasida, 1999),

Table 5. Physiological functions of minor components contained in soybeans.

\begin{tabular}{|c|c|}
\hline Isoflavones & $\begin{array}{l}\text { Anticarcinogenic activities }{ }^{a)} \text {, prevention of cardiovascu- } \\
\text { lar diseases }^{b)} \text {, prevention of osteoporosis }{ }^{c)} \text {, antioxidant } \\
\text { activeties }^{d)} \text {, and alleviation of menopausal symptoms }{ }^{e} \text {. }\end{array}$ \\
\hline Saponins & $\begin{array}{l}\text { Anticarcinogenic activities }{ }^{a, f), g} \text {, hypocholesterolemic } \\
\text { effects }^{f} \text {, Inhibition of platelet aggregation, HIV } \\
\text { preventing effects (group B saponin) })^{h)} \text {, and antioxidant } \\
\text { activities (DDMP saponin) })^{i} \text {. }\end{array}$ \\
\hline Phytosterol & Anticarcinogenic activities $^{a}$. \\
\hline Phytic acid & Anticarcinogenic activities ${ }^{a), f}$. \\
\hline $\begin{array}{l}\text { Lectin } \\
\text { (Hemagglutinin) }\end{array}$ & $\begin{array}{l}\text { Activation of lymphocytes }(\mathrm{T} \text { cell })^{h)} \text { and aggregating } \\
\text { action of tumor cells }{ }^{h)} \text {. }\end{array}$ \\
\hline Nicotianamine & Inhibitor of angiotensin-converting enzymes ${ }^{j, k}$. \\
\hline Protease inhibitors & Anticarcinogenic activities ${ }^{a), f}$. \\
\hline \multicolumn{2}{|c|}{$\begin{array}{l}\text { a) Hawrylewicz et al. }(1995) ;{ }^{b} \text { Setchell and Cassidy (1999); }{ }^{c} \text { Anderson and } \\
\text { Garner (1997); }{ }^{d)} \text { Yoshiki and Okubo (1997); }{ }^{e)} \text { Albertazzi et al. (1998); } \\
\text { (j) Messina and Barnes (1991); }{ }^{g)} \text { Rao and Sung (1995); }{ }^{h} \text { Harada (1999); } \\
\left.{ }^{i}\right) \text { Yoshiki and Okubo (1995); }{ }^{j} \text { Kinoshita et al. (1993); and }{ }^{k} \text { Kinoshita et al. } \\
\text { (1994). }\end{array}$} \\
\hline
\end{tabular}


whereas that in Japanese-style fermented soy and sauce is very high, namely around $230 \mathrm{ppm}$. HEMF is effective when it is fed to mouse at $4 \mathrm{mg} / \mathrm{kg}$ body wt./day, indicating that it is a potent anticarcinogen. As another physiological effect, fermented soy sauce has the activity to inhibit angiotensin I-converting enzyme, but this activity is mostly ascribed to nicotianamine (Kinoshita et al., 1994), which is the constituent of soybeans (see Table 5).

Natto made through the fermentation by Bacillus natto has a strong fubrinolytic activity, which is due to the enzyme named nattokinase, produced by Bacillus natto (Sumi et al., 1987). Natto also has anti-tumor-promoting activity, because the extract prevented the reduction of dye transfer caused by a typical tumor promoter of 12-O-tetradecanoylphorbol-13-acetate (Takahashi et al., 1995). Besides these, natto possesses the activities to inhibit angiotensin I-converting enzyme, as soy sauce does (Okamoto et al., 1995). The substances responsible for these activities have not been elucidated yet. However, it is certain that nicotianamine does not relate to these activities, because it disappears during the fermentation of natto (Kinoshita et al., 1994).

\section{Physicochemical Functions of Soybean Storage Proteins}

Approximately $90 \%$ of the proteins in soybeans exist as storage proteins, which mostly consist of $\beta$-conglycinin and glycinin. $\beta$-Conglycinin (Koshiyama, 1965; Catsimpoolas \& Ekenstam, 1969; Koshiyama \& Fukushima, 1976a) has the sedimentation coefficients of 7S, whereas glycinin (Mitsuda et al., 1965) has that of $11 \mathrm{~S}$. Besides $\beta$-conglycinin, there are two kinds of globulins which have the sedimentation coefficient of 7S. They are $\gamma$-conglycinin (Catsimpoolas \& Ekenstam, 1969; Koshiyama \& Fukushima, 1976b) and basic 7S globulin (Yamauchi et al., 1984). However, these two 7S globulins are minor components which account for less than a few percent. The major storage proteins of $\beta$-conglycinin and glycinin possess a variety of functional properties physicochemically for food applications as shown in the introduction. These functional properties are ascribed to the intrinsic physicochemical characteristics which are based on the molecular structures. Therefore, this chapter focuses on recent developments in the structure-function relationship of $\beta$-conglycinin and glycinin.

Basic structures of $\beta$-conglycinin and glycinin molecules $\beta$-Conglycinin is a glycoprotein and a trimer with a molecular mass of 150-200 kDa. Major subunits are $\alpha^{\prime}$ (72 $\mathrm{kDa}), \alpha(68 \mathrm{kDa})$, and $\beta$ (52 kDa) (Thanh \& Shibasaki, 1977). Besides these, there is a minor subunit called $\gamma$ in $\beta$-conglycinin (Thanh \& Shibasaki, 1977). The amino acid sequences of these subunits are similar each other (Hirano et al., 1987). Each of $\alpha$ ' and $\alpha$ subunits possesses one cysteine residue (-SH) near the $\mathrm{N}$ termini, whereas $\beta$ subunit does not possess any cysteine residue (Utsumi et al., 1997). No cystine residues (-SS-) exist in these subunits. $\beta$-Conglycinin exhibits molecular heterogeneity, where six molecular species are identified as $\alpha^{\prime} \beta_{2}, \alpha \beta_{2}, \alpha \alpha^{\prime} \beta, \alpha_{2} \beta$, $\alpha_{2} \alpha^{\prime}$, and $\alpha_{3}$ (Thanh \& Shibasaki, 1978; Yamauchi et al., 1981). In addition, Yamauchi et al. (1981) found another species of $\beta_{3}$. $\beta$-Conglycinin trimers cause association or dissociation depending upon the $\mathrm{pHs}$ and ionic strengths of the solution (Thanh \& Shibasaki, 1979).

Glycinin is a hexamer with a molecular mass of 300-380 kDa. Each subunit is composed of acidic $(\sim 35 \mathrm{kDa})$ and basic $(\sim 20$ $\mathrm{kDa})$ polypeptides, which are linked together by a disulfide bond
Table 6. Functional properties of soybean storage proteins and their subunits working physicochemically in food systems.

\begin{tabular}{|c|c|c|}
\hline Functionality & $\begin{array}{l}\text { Proteins or } \\
\text { subunits }\end{array}$ & Property or its difference \\
\hline \multirow{5}{*}{ Gel formation } & $\beta$-Conglycinin & $\begin{array}{l}\text { Transparent, soft, but rather elastic } \\
\text { gel. }\end{array}$ \\
\hline & Glycinin & Turbid, hard, and not so fragile gel. \\
\hline & $\mathrm{A}_{2} \mathrm{~B}_{1 \mathrm{a}}$ subunit & $\begin{array}{l}\mathrm{A}_{2} \text { polypeptide relates to gel } \\
\text { hardness. }\end{array}$ \\
\hline & $\mathrm{A}_{3} \mathrm{~B}_{4}$ subnunit & $\begin{array}{l}\mathrm{A}_{3} \text { polypeptide relates to gel } \\
\text { hardness. }\end{array}$ \\
\hline & $\mathrm{A}_{5} \mathrm{~A}_{4} \mathrm{~B}_{3}$ subunit & $\begin{array}{l}\mathrm{A}_{5} \mathrm{~A}_{4} \mathrm{~B}_{3} \text { subunit relates to the easiness } \\
\text { of gel formation. }\end{array}$ \\
\hline \multirow{2}{*}{ Thermal stability } & $\begin{array}{l}\text { Soybean storage } \\
\text { proteins }\end{array}$ & $\beta$-Conglycinin $<$ Glycinin \\
\hline & $\begin{array}{l}\beta \text {-Conglycinin } \\
\text { subunits }\end{array}$ & $\alpha<\alpha^{\prime}<\beta$ \\
\hline \multirow[t]{2}{*}{ Emulsification } & $\begin{array}{l}\text { Soybean storage } \\
\text { protein }\end{array}$ & $\beta$-Conglycinin $>$ Glycinin \\
\hline & $\begin{array}{l}\beta \text {-Conglycinin } \\
\text { Subunits }\end{array}$ & $\alpha \geqq \alpha^{\prime} \gg \beta$ \\
\hline
\end{tabular}

Source: Utsumi et al. (1997).

(Staswick et al., 1984). In glycinin, five subunits are identified as $\mathrm{A}_{1 \mathrm{a}} \mathrm{B}_{1 \mathrm{~b}}(53.6 \mathrm{kDa}), \mathrm{A}_{2} \mathrm{~B}_{1 \mathrm{a}}(52.4 \mathrm{kDa}), \mathrm{A}_{1 \mathrm{~b}} \mathrm{~B}_{2}$ (52.2 kDa), $\mathrm{A}_{5} \mathrm{~A}_{4} \mathrm{~B}_{3}$ $(61.2 \mathrm{kDa})$ and $\mathrm{A}_{3} \mathrm{~B}_{4}(55.4 \mathrm{kDa})$, which are classified into group I $\left(A_{1 a} B_{1 b}, A_{2} B_{1 a}, A_{1 b} B_{2}\right)$ and group II $\left(A_{5} A_{4} B_{3}, A_{3} B_{4}\right)$ by the extent of the homology (Nielsen, 1985; Nielsen et al., 1989). Each subunit in group I has two cysteine and three cystine residues, whereas that in group II has two cysteine and two cystine residues (Utsumi et al., 1997). Glycinin subunits exhibit polymorphism, that is, there are some amino acid replacements in the same kind of subunit among soybean cultivars (Mori et al., 1981; Utsumi et al, 1987). Moreover, glycinin exhibits molecular heterogeneity, because the molecule is a hexamer with different subunit composition (Utsumi et al., 1981). Glycinin hexamers dissociate to their constituent polypeptides, subunits, and half-molecules, depending upon $\mathrm{pHs}$, ionic strengths, and heating temperatures (Wolf \& Briggs, 1958; Mori et al., 1982).

Physicochemical functionalities and three-dimensional structures of protein molecules The difference of the functionalities on the gel formation, thermal stability, and emulsification, in soybean storage proteins and their subunits is shown in Table 6 (Utsumi et al., 1997). The mechanisms on the gel formation of $\beta$-conglycinin (Nakamura et al., 1986) and glycinin (Mori et al., 1982; Nakamura et al., 1984) are studied in details. Glycinin forms a turbid, hard, and not fragile gel, whereas $\beta$-conglycinin forms a transparent, soft, but rather elastic gel, in $100^{\circ} \mathrm{C}$ heating (Utsumi et al, 1997). The $\mathrm{A}_{2}$ polypeptide of glycinin $\mathrm{A}_{2} \mathrm{~B}_{1 \mathrm{a}}$ subunit closely relates to gel turbidity, whereas the $A_{3}$ polypeptide of the $A_{3} B_{4}$ subunit relates to the gel hardness. The hardness of glycinin gel increases in proportion to the content of $\mathrm{A}_{3}$ polypeptide. The $A_{5} A_{4} B_{3}$ subunit relates to the easiness of gel formation, because of the easy cleavage of the hydrophobic bonds between the $A_{5}$ and $A_{4}$ acidic chains during heating. $\beta$-Conglycinin is more unstable thermally than glycinin, but the emulsifying and emulsion-stabilizing abilities of $\beta$-conglycinin are much stronger than those of glycinin.

The physicochemical functions of proteins depend upon their three-dimensional structures substantially. The polypeptide chains of the protein molecules are unfolded through the heat treatment of soybeans and as a result the amino acid side resi- 
Table 7. Number of cysteine and cystine in each subunit of $\beta$-conglycinin and glycinin.

\begin{tabular}{lccc}
\hline & Subunit & Cysteine (-SH) & Cystine (-SS-) \\
\hline \multirow{3}{*}{ 3-Conglycinin } & $\alpha$ & 1 & 0 \\
& $\alpha$ & 1 & 0 \\
& $\beta$ & 0 & 0 \\
\hline \multirow{5}{*}{ Glycinin } & $\mathrm{A}_{1 \mathrm{a}} \mathrm{B}_{1 \mathrm{~b}}$ & 2 & 3 \\
& $\mathrm{~A}_{2} \mathrm{~B}_{1 \mathrm{a}}$ & 2 & 3 \\
& $\mathrm{~A}_{1 \mathrm{~b}} \mathrm{~B}_{2}$ & 2 & 3 \\
& $\mathrm{~A}_{3} \mathrm{~B}_{4}$ & 2 & 2 \\
& $\mathrm{~A}_{5} \mathrm{~A}_{4} \mathrm{~B}_{3}$ & 2 & 2
\end{tabular}

Source: Utsumi et al. (1997).

dues buried inside a molecule are exposed on the surface. The exposed -SH or hydrophobic residues combine the protein molecules through - $\mathrm{SH}$, -SS- interchange reaction or hydrophobic bonding, respectively. In this case, it is very important that these active residues are present at an accessible location of the molecules each other. Table 7 shows the numbers of -SH and -SSgroups in each subunit. The larger numbers of -SH groups and their topology in glycinin make glycinin gel much harder and more turbid in comparison with $\beta$-conglycinin gel, whereas the higher hydrophobicity and more easily unfolded structure in $\beta$ conglycinin make its emulcifying ability much stronger than that of glycinin (Utsumi et al., 1997).

In order to improve these functional properties, it is necessary to know about the theoretical relations between the functional properties and the three-dimensional structures of the molecules. The research on the three-dimensional structures of soybean stor-

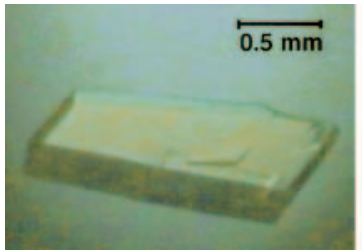

(A)

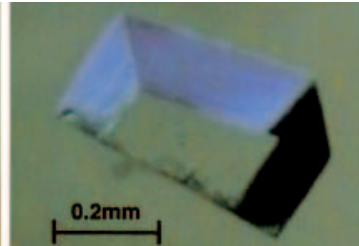

(B)
Fig. 3. The crystals of $\beta$-conglycinin $\beta$ homotrimer (A) and glycinin $A_{3} B_{4}$ homohexamer (B) (By the courtesy of Dr. S. Utsumi).

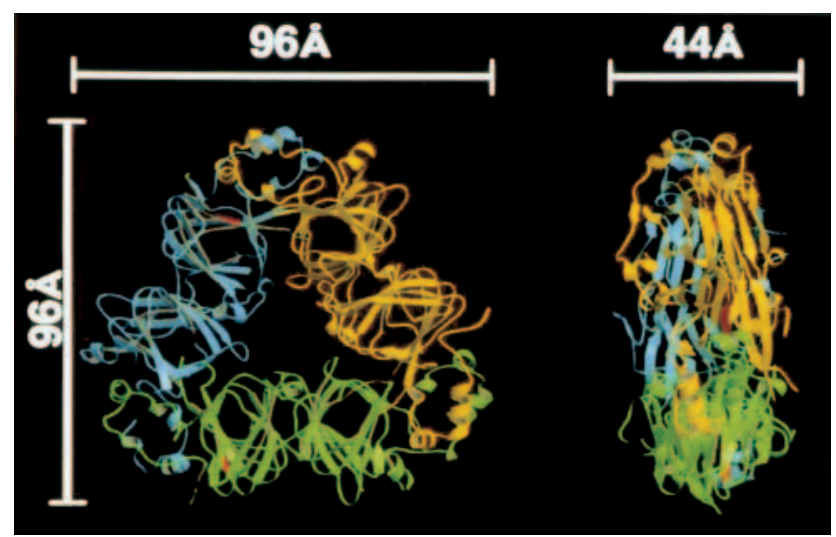

Fig. 4. Three-dimensional molecular structures of $\beta$-conglycinin $\beta$ homotrimer (By the courtesy of Dr. S. Utsumi). age proteins started 35 years ago. We investigated the threedimensional structures of $\beta$-conglycinin and glycinin molecules through optical rotatory dispersion (ORD), circular dichroism (CD), infrared absorption spectra, ultra-violet difference spectra, deutration studies, etc. (Fukushima; 1965, 1967, and 1968). However, these methods are the indirect ones for the measurement of three-dimensional structures. For a direct and complete analysis of three-dimensional structures, soybean proteins must be crystallized, followed by a X-ray crystallographic analysis. The complete amino acid sequence of molecular subunits of soybean storage proteins has been determined in early 1980s through the sequence analysis of full-length cDNA and a genomic clone (see the review of Fukushima, 1988, 1991a, and 1991b). For a long time, however, the X-ray analysis of soybean proteins have not been carried out, because the molecular heterogeneities in both $\beta$-conglycinin and glycinin obstructed their crystallization. Utsumi's group has overcome these difficulties by using a special soybean variety, of which $\beta$-conglycinin molecules or glycinin molecules are composed of the same kinds of subunits $\left[\beta\right.$ homotrimer $(3 \beta)$ in $\beta$-conglycinin and $\mathrm{A}_{3} \mathrm{~B}_{4}$ homohexamer $(6$ $A_{3} B_{4}$ ) in glycinin]. Thus, they have succeeded in the crystallization of both $\beta$ homotrimer $\beta$-conglycinin and $\mathrm{A}_{3} \mathrm{~B}_{4}$ homohexamer glycinin (see Fig. 3) and in the subsequent X-ray crystallographic analysis of the three-dimensional structures of their molecules (Maruyama et al.,1999; Adachi et al., 1999). The schematic diagrams of the polypeptides are shown in Fig. 4 and 5 (Fukushima, 2000b). The success of the complete analysis of the three-dimensional structures should be mentioned to be epoch-making in knowing the mechanisms of the functionalities of soybean proteins, because most of the properties of proteins are ascribed to the conformation of the molecular surface in the three-dimensional structures of the molecules. Furthermore, the

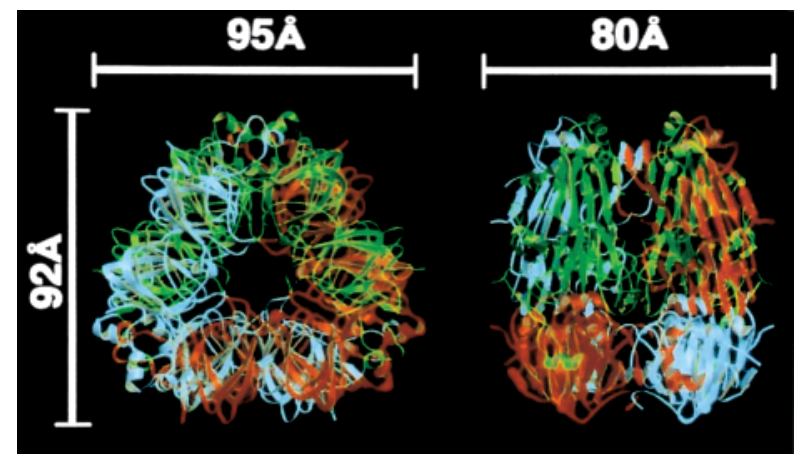

Fig. 5. Three-dimensional molecular structures of glycinin $\mathrm{A}_{3} \mathrm{~B}_{4}$ homohexamer (By the courtesy of Dr. S. Utsumi).

Table 8. Contents of secondary structures contained in soybean storage proteins molecules.

\begin{tabular}{|c|c|c|c|c|}
\hline & \multicolumn{2}{|c|}{$\beta$-Conglycinin } & \multicolumn{2}{|c|}{ Glycinin } \\
\hline & X-ray ${ }^{a)}$ & $\mathrm{CD}^{b)}$ & X-ray ${ }^{a}$ & $\mathrm{CD}^{b)}$ \\
\hline$\alpha$-Helix & 10 & 5 & 8 & 5 \\
\hline$\beta$-Structure & 33 & 35 & 36 & 35 \\
\hline Disordered structure & 57 & 60 & 56 & 60 \\
\hline
\end{tabular}

${ }^{a}$ Values obtained by X-ray crystallographic method. ${ }^{b}$ Values obtained by circular dichroism method. 
elucidation of the detailed three-dimensional structures enables us the theoretical modifications of the molecules, leading into the improvement of soybean protein properties through the protein engineering. Table 8 shows the comparison between the X-ray data of Utsumi's group (Fukushima, 2000b) and our ORC and CD data (Fukushima; 1965, 1967, and 1968; Koshiyama \& Fukushima, 1973) on the per cent of the secondary structures. It is very interesting that the results of X-ray analysis are in good accordance with the results by our indirect $\mathrm{CD}$ method around 30 years ago.

\section{Quality Improvement of Soy Food Products}

Off-flavors and allergenic proteins in soybeans The most difficult problem limiting the expanded use of soy protein products in the Western countries is strong off-flavors associated with these products. There are two types of off-flavors. One is grassy and beany flavors and the other is bitter, astringent, and chalky flavors. The grassy-beany flavors are developed through the action of the three kinds of lipoxygenases 1,2, and 3 present at soybeans. The bitter, astringent, and chalky flavors are caused by saponins and isoflavones (Okubo et al., 1992). The off-flavors of isoflavones are enhanced by the hydrolysis into their aglycones through the action of three kinds of $\beta$-glucosidases $\mathrm{A}, \mathrm{B}$, and $\mathrm{C}$ in soybeans (Matsuura \& Obata, 1993). Thus, both lipoxigenases and $\beta$-glucosidases contained in soybeans play an important role in the production or enhancement of the off-flavors. Moreover, the lipid hydroperoxides produced by lipoxygenases oxidize the free - $\mathrm{SH}$ groups of soybean proteins, resulting into the decrease of their gel-forming ability (Fukushima, 1994). For a long time, a variety of attempts to remove or mask these off-flavors have been done through the operation during processing. However, it was impossible to remove or mask the off-flavors to a satisfactory extent by these methods.

Table 9. Major allergenic proteins in soybeans ${ }^{b)}$.

\begin{tabular}{lcc}
\hline Protein assignment & Molecular wt. (k Da) & Frequency $^{a}(\%)$ \\
\hline Gly $m \mathrm{Bd} 30 \mathrm{k}$ & 30 & 65.2 \\
Gly $m \mathrm{Bd} 28 \mathrm{k}$ & 28 & 23.2 \\
$\alpha$ subunit of & 68 & 23.2 \\
$\beta$-conglycinin & & \\
$\beta$ subunit of & 45 & 10.1 \\
$\beta$-conglycinin & & \\
\hline
\end{tabular}

${ }^{a)}$ Detection frequency among 69 soybean-sensitive patients with atopic dermatitis. ${ }^{b}$ Source: Ogawa et al. (1991).
Another unbeneficial substance other than off-flavors in soybeans is allergenic proteins. The major allergenic proteins in soybeans are shown in Table 9 (Ogawa et al., 1991). It is noticeable that the two of the three subunits of $\beta$-conglycinin have allergenic proteins. It is impossible to remove all of these major allergens through usual treatments or processing.

Genetic improvement of soybeans In the last two decades, the various soybean mutant genes which control the production of enzymes, allergenic proteins, storage proteins, etc. have been identified in the world soybean germplasm. Using these mutants, the commercially available soybean cultivars without having undesirable substances or with the beneficially modified composition of storage proteins have been bred. As an example, there is the cultivar "Kunitz" [Illinois Agricultural Experiment Station (AES)] lacking Kunitz's soybean trypsin inhibitor (Bernard et al. 1991) or the cultivar "Ichihime" (Kyushu AES) lacking all of the lipoxygenases 1, 2, and 3 (Nishiba et al., 1995). The development of lipoxygenase-free cultivar will be beneficial for the production of non-traditional soy products, since Western people are very sensitive for beany flavors. However, the soybean cultivars lacking the $\beta$-glucosidases have not been developed yet, which are the enzymes enhancing the off-flavors by changing the isoflavones into their aglycones.

There was some progress on the removal of allergenic proteins recently. The cultivar with a high ratio of glycinin to $\beta$-conglycinin was developed by the group of Tohoku National AES, named Tohoku 124. This cultivar lacks the two major allergenic proteins of $28 \mathrm{~K}$ and $\alpha$ subunit, while it still possesses allergenic proteins of $30 \mathrm{~K}$ and $\beta$-subunit (Samoto, 1996). Fortunately, the 30K protein can be removed easily by centrifugation, which is bound to IgE antibodies most strongly and frequently. Another group of Kyushu National AES found the wild soybean line, named $\mathrm{QT}_{2}$, which lacks all of $\beta$-conglycinin (Hajika et al., 1998). This line grows normally and produces successive generations, indicating the possibility to breed the soybean varieties, of which storage proteins are mainly composed of glycinin without containing any $\beta$-conglycinin. Using this $\mathrm{QT}_{2}$ line, they obtained the line lacking all the subunits of $\beta$-conglycinin by back-crossing with Fukuyutaka. This line contains only glycinin as storage proteins and that it lacks the three major allergenic proteins of $28 \mathrm{~K}, \alpha$, and $\beta$ subunits (Takahashi et al., 2000). This had so good field performance as Fukuyutaka in the on-campus experiment and was named Kyu-kei 305. Kyu-kei 305 should be mentioned to be the variety with the least quantities of allergens so far. Besides these,

Table 10. Hardness of tofu gel made from soybeans with different ratio of both $11 \mathrm{~S} / 7 \mathrm{~S}$ proteins and glycinin subunit compositions.

\begin{tabular}{|c|c|c|c|c|c|}
\hline \multirow{2}{*}{ Breeding line } & \multicolumn{3}{|c|}{ Glycinin subunit } & \multirow{2}{*}{$11 \mathrm{~S} / 7 \mathrm{~S}$ in soy milk } & \multirow{2}{*}{ Breaking stress of tofu gel } \\
\hline & Group I & $\mathrm{A}_{5} \mathrm{~A}_{4} \mathrm{~B}_{3}$ & $\mathrm{~A}_{3} \mathrm{~B}_{4}$ & & \\
\hline Enrei (control) & + & - & + & $58 / 42$ & 9,891 \\
\hline $\mathrm{EnB}_{2}-111$ & + & + & + & $66 / 34$ & 9,989 \\
\hline $\mathrm{EnB}_{2}-110$ & + & + & - & $62 / 38$ & 8,955 \\
\hline $\mathrm{EnB}_{2}-101$ & + & - & + & $57 / 43$ & 10,171 \\
\hline $\mathrm{EnB}_{2}-100$ & + & - & - & $45 / 55$ & 7,162 \\
\hline $\mathrm{EnB}_{2}-011$ & - & + & - & $52 / 48$ & 6,791 \\
\hline $\mathrm{EnB}_{2}-010$ & - & + & - & $33 / 67$ & 4,835 \\
\hline $\mathrm{EnB}_{2}-001$ & - & - & + & $25 / 75$ & 5,381 \\
\hline $\mathrm{EnB}_{2}-000$ & - & - & - & $12 / 88$ & 3,002 \\
\hline
\end{tabular}

Crops: Enrei (control), $380 \mathrm{~kg}$; and others, 384-441 Kg/10 a. Protein content of seeds: Enrei (control), 42\%; and others, 39.3-40.7\%. Source: Yagasaki et al. (1999). 
the eight isogenic breeding lines with a different ratio of glycinin to $\beta$-conglycinin have been obtained by back-crossing, using Enrei as a recurrent parent in Nagano Chushin Experiment Station (Yagasaki et al., 1999). In each of these lines, not only the ratio of glycinin to $\beta$-conglycinin, but also the subunit composition of glycinin is varied systematically (see Table 10). The breaking stress of tofu gels made from the soybeans of these lines increases markedly with the increase of the contents of glycinin and its $\mathrm{A}_{3} \mathrm{~B}_{4}$ subunit. The yields and protein contents of the soybean seeds in these lines are substantially the same as the parent Enrei, indicating the possibility of the breeding of a practical cultivar.

Now that the three-dimensional structures have been elucidated completely in the molecules of $\beta$-conglycinin and glycinin, it is possible to improve the qualities of soybean storage proteins both physiologically and physicochemically through a genetic modification. For instance, Kim et al. (1990) made a modified $A_{1 a} B_{1 b}$ gene which has four additional methionyl residues near the $\mathrm{C}$-termini. This modified $\mathrm{A}_{1 \mathrm{a}} \mathrm{B}_{1 \mathrm{~b}}$ is excellent in both gelling and emulsifying properties. If this gene is introduced into the soybean lines lacking $\beta$-conglycinin such as Kyu-kei 305, the resultant transgenic soybeans are expected to have beneficial functional properties in food systems, together with a high content of methionine. We can also improve the properties of the storage proteins by introducing various kinds of physiologically active peptides into the molecules on the basis of the threedimensional structures. In addition, transgenic rice (Momma et al., 1999) and potato (Utsumi et al., 1994) with glycinins have already been bred. On soybean oil, the genetic modification of the fatty acid composition has been carried out for the increase of the oil stability. As a result, soybean lines with oleic, linoleic, and linolenic acids of 85,3 , and $3 \%$, respectively, have been developed (Krebbers et al., 1997).

\section{Conclusion}

For the long time, the removal of off-flavors has been a primary concern in research and technology on the utilization of soybeans for non-traditional foods. At present, however, the concern is switching over to the physiological active substances as well as the physicochemical functions of soybeans in food systems. For instance, isoflavones were considered simply as undesirable substances having strong off-flavors, but now their image has been changed to the useful substances with an excellent preventive or alleviating effect to cancer, osteoporosis, and menopausal symptoms, etc. However, it should be considered that the isoflavones are the substances having both favorable and unfavorable properties for the development of new soy products. The creation of new soybean cultivars is one of the most effective methods to obtain new soy products with a preferable character, because the desirable or undesirable components of soybeans can be controlled essentially at a DNA level, in either conventional breeding or modern genetic engineering. Now that the preventive effects of soybeans on chronic diseases have been proved scientifically, the future of soybeans must be bright. It is no doubt that the year of 2001, is surely the dawn of the innovative era for the technology of soybeans.

\section{References}

Adachi, M., Masuda, T., Kanamori, J., Yagasaki, K., Kitamura, K.,
Kaneda, Y., Mikami, B. and Utsumi, S. (1999). Crystallization and $\mathrm{X}$-ray crystallographic analysis of matured $\mathrm{A}_{3} \mathrm{~B}_{4}$ hexamer in soybean glycinin. Nippon Nogeikagaku Kaishi, 73(S), 102 (in Japanese).

Albertazzi, P., Pansini, F., Bonaccorsi, G., Zanotti, L., Forini, E. and De Aloysio, D. (1998). The effect of dietary soy supplementation on hot flushes. Obstet. Gynecol., 91, 6-11.

Anderson, J.J.B. and Garner, S.C. (1997). The effect of phytoesterogens on bone. Nutr. Res., 17, 1617-1632.

Anderson, J.W., Johnstone, B.M. and Cook-Newell, M.E. (1995). Meta-analysis of the effects of soy protein intake on serum lipids. New Engl. J. Med., 333, 276-282.

Bernard, R., Hymowitz, T. and Cremeens, C.R. (1991). Registration of 'Kunitz' soybean. Crop Sci., 31, 232-233.

Catsimpoolas, N. and Ekenstam, C. (1969). Isolation of alpa, beta, and gamma conglycinin. Arch. Biochem. Biophys., 129, 490-497.

Chen, H-M, Muramoto, K. and Yamauchi, F. (1995). Structural analysis of antioxidative peptides from soybean $\beta$-conglycinin. J. Agric. Food Chem., 43, 574-578.

Descovich, G.C., Ceredi, C., Gaddi, A., Benassi, M.S., Mannino, G., Colombo, L., Cattin, L., Fontana, G., Senin, U., Mannarino, E., Caruzzo, C., Bertelli, E., Fragiacome, C., Noseda, G., Sirtori, M. and Sirtori, C. R. (1980). Multicentre study of soybean protein diet for outpatient hypercholesterolemic patients. Lancet (October), 4, 709-712.

Fukushima, D. (1965). Internal structure of soybean protein molecule (11S protein) in aqueous solution. J. Biochem., 57, 822-823.

Fukushima, D. (1967). Optical rotatory dispersion (fur ultraviolet region), infrared absorption, and deutration studies of soybean proteins (7S and 11S). Agric. Biol. Chem., 31, 130-132.

Fukushima, D. (1968). Internal structure of 7S and 11S globulin molecules in soybean proteins. Cereal Chem., 45, 203-224.

Fukushima, D. (1980). Deteriorative changes of proteins during soybean food processing and their use in foods. In "Chemical Deterioration of Proteins, ACS Symposium Series 123," ed. by J. R. Whitaker and M. Fujimaki. American Chemical Society, Washington D.C., pp. 211-240.

Fukushima, D. (1981). Soy proteins for foods centering around soy sauce and tofu. J. Am. Oil Chem. Soc., 58, 346-354.

Fukushima, D. (1985). Fermented vegetable protein and related foods of Japan and China. Food Rev. Int., 1, 149-209.

Fukushima, D. (1988). Recent knowledge on molecular structures of seed storage proteins. In "Progress of Science and Technology in Food Industry" (III), ed. by Jpn. Soc. for Food Sci. Technol. Korin Publishing Co., Ltd., Tokyo, p. 21-49.

Fukushima, D. (1989). Industrialization of fermented soy sauce production centering around Japanese shoyu. In "Industrialization of Indigenous Fermented Foods," ed. by K. H. Steinkraus. Marcel Dekker, Inc., New York and Basel, 1-88.

Fukushima, D. (1991a). Recent progress of soybean protein foods: chemistry, technology, and nutrition. Food Rev. Int., 7(3), 323-351.

Fukushima, D. (1991b). Structures of plant storage proteins and their functions. Food Rev. Int., 7, 353-381.

Fukushima, D. (1994). Recent progress on biotechnology of soybean proteins and soybean protein food products. Food Biotechnol., 8, 83-135.

Fukushima, D. (2000a). Soybean processing. In "Food Proteins: Processing Applications," ed. by S. Nakai and H. W. Modler. WileyVCH, Inc., New York and Tronto, pp. 309-342.

Fukushima, D. (2000b). Recent progress in research and technology for processing and utilization of soybeans. In "Proceedings of the Third International Soybean Processing and Utilization Conference," ed. by Jpn. Soc. for Food Sci. Technol. Korin Publishing Co., Ltd., Tokyo, pp. 11-16.

Fukushima, D. and Hashimoto, H. (1980). Oriental soybean foods. In "Processing of World Soybean Research Conference II," ed. by F.T. Corbln. Westview Press, Boulder, Colorado, pp. 729-743.

Hajika, M., Takahashi, M., Sakai, S. and Matsunaga, R. (1998). Dominant inheritance of a trait lacking $\beta$-conglycinin detected in a wild soybean line. Breeding Sci., 48, 383-386.

Harada, H. (1999). Soybeans as attractive foodstuffs. Res. J. Food 
Agric., 22, 27-32.

Hawrylewicz, E.J., Zapata, J.J. and William, H.B. (1995). Soy and experimental cancer: animal studies. J. Nutr., 125, 698S-708S.

Hayashida, Y. (1999). 4-Hydroxy flanones in mugi-miso flavor. $J$. Brewing Soc. Jpn., 94, 527-534.

Hirano, H., Kagawa, H., Kamata, Y. and Yamauchi, F. (1987). Structural homology among the major $7 \mathrm{~S}$ globulin subunits of soybean seed storage proteins. Phytochemistry, 26, 41-45.

Iritani, N., Hosomi, H., Fukuda, H., Tada, K. and Ikeda, H. (1996). Soybean protein suppresses hepatic lipogenic enzyme gene expression in Wistar fatty rats. J. Nutr., 126, 380-388.

Iwami, K., Sakakibara, K. and Ibuki, F. (1986). Involvement of postdigestion 'hydrophobic' peptides in plasma cholesterol-lowering effect of dietary plant proteins. Agric. Biol. Chem., 50, 1217-1222.

Joint FAO/WHO/UNU Expert Consultation. (1985). Energy and protein requirement. WHO Technical Report Series, No. 724, p. 121.

Kawamura, S. (1997). Peptides from soybean globulins with the action to inhibit angiotensin-converting enzymes and their effects to blood pressure. Food Ind., 40, 73-82.

Kim, C., Kamiya, S., Sato, T., Utsumi, S. and Kito, M. (1990). Improvement of nutritional value and functional properties of soybean glycinin by protein engineering. Protein Engng., 3, 725-731.

Kinoshita, E., Yamakoshi, J. and Kikuchi, M. (1993). Purification and identification of an angiotensin I-converting enzyme inhibitor from soy sauce. Biosci. Biotechnol. Biochem., 57, 1107-1110.

Kinoshita, E., Yamakoshi, J. and Kikuchi, M. (1994). Blood pressure lowering substance in soy sauce. J. Brewing Soc. Jpn., 89, 126-130.

Koshiyama, I. (1965). Purification of the $7 \mathrm{~S}$ component of soybean proteins. Agric. Biol. Chem., 29, 885-887.

Koshiyama, I. and Fukushima, D. (1973). Comparison of conformation of $7 \mathrm{~S}$ and $11 \mathrm{~S}$ soybean globulins by optical rotatory dispersion and circular dichroism studies. Cereal Chem., 50, 114-121.

Koshiyama, I. and Fukushima, D. (1976a). Identification of the 7S globulin with $\beta$-conglycinin in soybean seeds. Phytochemistry, 15, 157-159.

Koshiyama, I. and Fukushima, D. (1976b). Purification and some properties of $\gamma$-conglycinin in soybean seeds. Phytochemistry, 15, 161164.

Krebbers, E., Broglie, R., Hitz, B., Jones, T. and Hubbard, N. (1997). Biotechnological approaches to altering seed composition. In "Cellular and Molecular Biology of Plant Seed E Developmen," ed. by B.A. Larkins and I.K. Vasil. Kluwer Academic Publishers, pp. 595633.

Liu, K. (2000). Expanding soybean food utilization. Food Technol., 54, 46-58.

Lovati, M.R., Manzoni, C., Corsini, A., Granata, A., Frattini, R., Fumagalli, R. and Sirtori, C. R. (1992). Low density lipoprotein receptor activity is modulated by soybean globlins in cell culture. J. Nutr., 122, 1971-1978.

Maruyama, N., Adachi, M., Kono, M., Yagasaki, T., Nakagawa, S., Okuda, H., Mikami, B. and Utsumi, S. (1999). Crystallization and $\mathrm{X}$-ray crystallographic analysis of naturtal $3 \beta$ trimer in soybean $\beta$ conglycinin. Nippon Nogeikagaku Kaishi, 73(S), 102 (in Japanese).

Matsuura, M. and Obata, A. (1993). $\beta$-Glucosidases from soybeans hydrolyze daidzin and genestin. J. Food Sci., 58, 144-147.

Messina, M. and Barnes, S. (1991). The role of soy products in reducing risk of cancer. J. Natl. Cancer Inst., 83, 541-546.

Minami, K., Moriyama, R., Kitagawa, K. and Makino, S. (1990). Identification of soybean protein components that modulate the action of insulin in vitro. Agric. Biol. Chem., 54, 511-517.

Mitsuda, H., Kusano, T. and Hasegawa, K. (1965). Purification of the $11 \mathrm{~S}$ component of soybean proteins. Agric. Biol. Chem., 29, 7-12.

Momma, K., Hashimoto, W., Ozawa, S., Kawai, S., Katsube, T., Takaiwa, F., Kito, M., Utsumi, S. and Murata, K. (1999). Quality and safety evaluation of genetically engineered rice with soybean glycinin: analysis of the grain composition and digestibility of glycinin in transgenic rice. Biosci. Biotechnol. Biochem., 63, 314-318.

Mori, T., Utsumi, S., Inaba, H., Kitamura, K. and Harada, K. (1981). Differences in subunit composition of glycinin among soybean cultivars. J. Agric. Food Chem., 29, 20-23.

Mori, T., Nakamura, T. and Utsumi, S. (1982). Gelation mechanism of soybean 11S globulin: formation of soluble aggregates as transient intermediates. J. Food Sci., 47, 26-30.

Nagahara, A., Benjamin, H., Stopkson, J., Krewson, J., Sang, K., Liu, W. and Pariza, M.W. (1992). Inhibition of benzo [ $\alpha$ ] pyren-induced mouse forestomach neoplasia by a principal flavor component of Japanese-style fermented soy sauce. Cancer Res., 52, 1754-1956.

Nakamura, T., Utsumi, S. and Mori, T. (1984). Network structure formation in thermally induced gelation of glycinin. J. Agric. Food Chem., 32, 349-352.

Nakamura, T., Utsumi, S. and Mori, T. (1986). Mechanism of heatinduced gelation and gel properties of soybean $7 \mathrm{~S}$ globulins. Agric. Biol. Chem., 50, 1287-1293.

Nielsen, N.C. (1985). The structure and complexity of the $11 \mathrm{~S}$ polypeptides in soybeans. J. Am. Oil Chem. Soc., 62, 1680-1686.

Nielsen, N.C., Dickinson, C.D., Cho, T.J., Thanh, V.H., Scallon, B.J., Fischer, R.L., Sims, T.L., Drews, G.N. and Goldberg, R.B. (1989). Characterization of the glycinin gene family in soybean. Plant Cell, 1, 313-328.

Nishiba, Y., Furuta, S., Hajika, M., Igita, K. and Suda, I. (1995). Hexanal accumulation and DETBA value in homogenate of soybean seeds lacking two or three lypoxygenase isozymes. J. Agric. Food Chem., 43, 738-741.

Ogawa, T., Bando, N., Tsuji, H., Okajima, H., Nishikawa, K. and Sasaoka, K. (1991). Investigation of the IgE-binding proteins in soybeans by immunoblotting with the sera of the soybean-sensitive patients with atopic dermatitis. J. Nutr. Sci. Vitaminol., 37, 555-565.

Okamoto, A., Hanagata, H., Kawamura, Y. and Yanagida, F. (1995). Anti-hypertensive substances in fermented soybean, natto. Plant Foods Human Nutr., 47, 39-47.

Okubo, K., Iijima, M., Kobayashi, Y., Yoshikoshi, M., Uchida, T. and Kubo, S. (1992). Components responsible for the undesirable taste of soybean seeds. Biosci. Biotechnol.Biochem., 56,99-103.

Potter, S. M. (1995). Overview of proposed mechanisms for the hypocholesterolemic effect of soy. J. Nutr., 125, 606S-611S.

Potter, S. M. (1998). Soy protein and cardiovascular disease: The impact of bioactive components in soy. Nutr. Rev., 56, 231-235.

Rao, A. V. and Sung, M. K. (1995). Saponins as anticarcinogens. $J$. Nutr., 125, 717S-724S.

Samoto, M., Miyazaki, C., Akasaka, T., Mori, H. and Kawamura, Y. (1996). Specific binding of allergenic soybean protein Gly $m$ 30K with $\alpha$ ' - and $\alpha$-subunits of conglycinin in soy milk. Biosci. Biotechnol. Biochem., 60, 1006-1010.

Sarwar, G., Peace, R.W. and Botting, H.G. (1985). Corrected relative net protein ratio (CRNPR) method based on differences in rat and human requirements for sulfur amino acids. J. Am. Oil Chem. Soc., 68, 689-693.

Sasaki, M. (1996). Isolation and identification of precursor of 4-hydroxy-2(or 5)-ethyl-5(or 2)-methyl-3(2H)-furanone from isolated soybean protein and shoyu. J. Agric. Food Chem., 44, 230-235.

Setchell, K. D. R. and Cassidy, A. (1999). Dietary isoflavones: biological effects and relevance to human health. J. Nutr., 129, 758S$767 \mathrm{~S}$.

Staswick, P.E., Hermodson, M.A. and Nielsen, N.C. (1984). Identification of the cysteines which link the acidic and basic components of the glycinin subunits. J. Biol. Chem., 259, 13431-13435.

Steinke, F. H. (1979). Measuring protein quality of foods. In "Soy Protein and Human Nutrition," ed. by H.L. Wilcke, D.T. Hopkins, and D.H. Waggle. Academic Press, New York.

Sugano, M., Yamada, Y., Yoshida, K., Hashimoto, Y., Matsuo, T. and Kimoto, M. (1988). The hypocholesterolemic action of the undigested fraction of soybean protein in rats. Atherosclerosis, 72, 115122.

Sugawara, E. (1991). Identification of 4-hydroxy-2(or 5)-ethyl-5(or 2)methyl-3(2H)-furanone as a flavor component in miso. Nippon Shokuhin Kogyo Gakkaishi, 38, 491-493 (in Japanese).

Sumi, H., Hamada, H., Tsushima, H., Mihara, H. and Muraki, H. (1987). A novel fibrinolytic enzyme (nattokinase) in the vegetable cheese Natto: a typical and popular soybean food in the Japanese diet. Experientia, 43, 1110-1111.

Takahashi, M., Hajika, M., Matsunaga, R., Komatsu, K., Obata, A. and Kanegae, R. (2000). Breeding of soybean variety lacking $\beta$-congly- 
cinin by the introduction of $S c g$ gene from wild soybean. In "The Proceedings of the Third International Soybean Processing and Utilization Conference." ed. by Jpn. Soc. Food Sci. Technol. p. 45-46.

Takahashi, C., Kikuchi, N., Katou, N., Miki, T., Yanagida, F. and Umeda, M. (1995). Possible anti-tumor-promoting activity of components in Japanese soybean fermented food, Natto: effect on gap junctional intercellular communication. Carcinogenesis, 16, 471476.

Tanaka, M., Kishi, K. and Yoshikawa, M. (1994). New phagocytosispromoting peptides derived from soybean proteins. Nippon Nogeikagaku Kaishi, 68, 341 (in Japanese).

Thanh, V. H. and Shibasaki, K. (1977). Beta-conglycinin from soybean proteins. Biochim. Biophys. Acta, 490, 370-384.

Thanh, V. H. and Shibasaki, K. (1978). Major proteins of soybean seeds. Subunit structure of $\beta$-conglycinin. J. Agric. Food Chem., 26, 692-695.

Thanh, V.H. and Shibasaki, K. (1979). Major proteins of soybean seeds. Reversible and irreversible dissociation of $\beta$-conglycinin. $J$. Agric. Food Chem., 27, 805-809.

Utsumi, S., Inaba, H. and Mori, T. (1981). Heterogeneity of soybean glycinin. Photochemistry, 20, 585-589.

Utsumi, S., Kim, C.S., Kohno, M. and Kito, M. (1987). Polymorphism and expression of cDNAs encoding glycinin subunits. Agric. Biol. Chem., 51, 3267-3273.

Utsumi, S., Kitagawa, S., Katsube, T., Higasa, T., Kito, M., Takaiwa, F. and Ishige, T. (1994). Expression and accumulation of normal molecular designed soybean glycininsins in potato tubers. Plant Sci., 102, 181-188.

Utsumi, S., Matsumura, Y. and Mori, T. (1997). Structure-function re- lationships of soy proteins. In "Food Proteins and Their Applications," ed. by S. Damodaran. and A. Paraf. Marcel Dekker, Inc., New York, pp. 257-291.

Wolf, W.J. and Briggs, D.R. (1958). Studies on the cold-insoluble fraction of the water-extractable soybean proteins. II. Factors influencing conformation changes in the $11 \mathrm{~S}$ component. Arch. Biochem. Biophys., 76, 377-393.

Yagasaki, K., Yamada, N., Takahashi, R. and Takahashi, N. (1999). Growth habit and tofu processing suitability of soybeans with different glycinin subunit composition. The Hokuriku Crop Sci., 34, 126128.

Yamauchi, F., Sato, M., Sato, W., Kamata, Y. and Shibasaki, K. (1981). Isolation and identification of a new type of $\beta$-conglycinin in soybean globulins. Agric. Biol. Chem., 45, 2863-2868.

Yamauchi, F., Sato, K. and Yamagishi, T. (1984). Isolation and partial characterization of a salt extractable globulin from soybean seeds. Agric. Biol. Chem., 48, 645-650.

Yoshikawa, M., Kishi, K., Takahashi, M., Watanabe, A., Miyamura, T., Yamazaki, M. and Chiba, H. (1993). Immunostimulating peptide derived from soybean peotein. Ann. N. Y. Acad. Sci., 685, 375-376.

Young, V. R. (1991). Soy protein in relation to human protein and amino acid nutrition. J. Am. Diet Assoc., 91, 828-835.

Yoshiki, Y. and Okubo, K. (1995). Active oxygen scavenging activity of DDMP (2, 3-dihydro-2, 5-dihydroxy-6-methyl-4H-pyran-4-one) saponin in soybean seed. Biosci. Biotechnol. Biochem., 59, 15561557.

Yoshiki, Y. and Okubo, K. (1997). Active oxygen scavenging activity in soybeans and soybean foods. Food Ind., 40, 77-86. 